\title{
JURORS ON TRIAL: LAWYERS USING THE INTERNET TO RESEARCH PROSPECTIVE JURORS
}

\author{
Lydia O'Hagan*
}

\begin{abstract}
This article examines a practice whereby lawyers use the internet to research prospective jurors with a view to challenge. It is unclear how common the practice is in New Zealand, but the increasing availability of personal information online means that lawyers have a plethora of personal information about prospective jurors at their fingertips. Currently peremptory challenges are exercised in a discriminatory fashion on the basis of broad stereotypes. It is argued that pretrial research by lawyers on prospective jurors could secure a more impartial jury by providing a mechanism for uncovering attitudinal biases or predispositions, meaning the challenges will be exercised on the basis of stereotypes alone less often. Pretrial research by lawyers could also remedy the disparity of resources between prosecution and defence by providing an independent vehicle for obtaining information. This article discusses the benefits of pretrial research of prospective jurors and argues that any drawbacks are limited. Potential guidelines for lawyers conducting pretrial research around the collection, use, retention and disclosure of information are proposed. This article concludes that pretrial research of prospective jurors serves to protect, rather than undermine, the fundamental right of all parties to a fair trial.
\end{abstract}

\section{WHOSE TRIAL IS IT ANYWAY?}

The use of technology by all parties in court proceedings has raised issues for courts in New Zealand and abroad. The rapid increase in the dissemination and preservation of information through social networking sites means that people have ready access to more personal information via the internet. Courts and academics alike have grappled with the question of how to manage the

* Article submitted as part of the LLB(Hons) programme at Victoria University of Wellington. I would like to thank my supervisor, Yvette Tinsley, who always delivered invaluable feedback, advice and support with a smile, throughout the writing of this paper. I would also like to thank my uncomplaining and patient father for making himself available to sound out ideas and proofread my work. 
use of this technology in a trial setting to ensure that all parties to a proceeding receive a fair trial. ${ }^{1}$ In relation to jury trials, this problem has two facets - research by jurors and research about jurors (by defendants or lawyers). This article looks at the merits and drawbacks of lawyers using the internet to research jurors with a view to challenge without cause (henceforth referred to as peremptory challenge).

Research by jurors, coined the problem of the "Googling Juror",2 has received a lot of attention in recent times. ${ }^{3}$ Jurors conducting their own internet research of cases in the United Kingdom have been convicted of contempt of court and sentenced to imprisonment. ${ }^{4}$ Concerns about the impact of technology are not confined to its use by jurors. The use of technology to garner information about jurors also appears to be increasing. For example, $P v R$, a case before the New Zealand Court of Appeal in 2012 concerned a convicted defendant (P) who used the internet to research the personal background of the foreperson of the jury that found him guilty. ${ }^{5}$ The jury had found the appellant guilty on six charges of performing an indecent act on a child under s 132(3) of the Crimes Act 1961. After his conviction, P uncovered communications on the juror's Facebook page, which he alleged were indicative of bias against his case. The communications included statements such as "people who assault children, sexually or physically, should receive harsh punishment", as well as criticisms of sentences handed down in unrelated cases of indecent acts on a minor. ${ }^{6} \mathrm{P}$ then lodged an appeal on three grounds, one being that the trial lawyer failed to challenge without cause the foreperson of the jury.

1 See David Harvey, Judge of the District Court of New Zealand "The Googling Juror: The Fate of the Jury Trial in the Digital Paradigm" (paper presented to 13th International Criminal Law Congress, Queenstown, September 2012); P v R [2012] NZCA 325; Attorney-General v Fraill \& Sewart [2011] EWHC 1629 (Admin); Attorney-General $v$ Dallas [2012] EWHC 156 (Admin). In the United States context, see Thaddeus Hoffmeister "Google, Gadgets, and Guilt: Juror Misconduct in the Digital Age" (2012) 83 UCOLR 409.

2 See Steven Price "Googling Jurors Again" (25 March 2009) Media Law Journal $<$ www.medialawjournal.co.nz >.

3 For an in-depth discussion of issues surrounding juror use of the internet, see Harvey, above n 1.

4 See Attorney-General v Fraill \& Sewart, above n 1; and Attorney-General v Dallas, above n 1. Joanne Fraill was convicted of contempt of court and sentenced to eight months' imprisonment for communicating with an acquitted defendant via Facebook while serving on the jury. Theodora Dallas, a juror, was sentenced to six months' imprisonment for contempt of court after telling her fellow jurors that the defendant had previously been accused of rape after conducting her own internet research.

$5 \quad P \vee R$, above $\mathrm{n} 1$.

6 At [13]. 
The Court of Appeal refused to entertain the ground of appeal, stating that the appellant's actions in conducting such research into the personal background of the particular juror were deplorable. ${ }^{7}$ The Court said that any action by a defendant, whether before, during or after trial that would encroach on the privacy and security of a juror or prospective juror would be viewed "extremely seriously" and may amount to contempt of court. ${ }^{8}$ However, the issue of lawyers researching jurors has not yet been the subject of investigation in the New Zealand context. It is not clear how widespread the practice is, but it has been the subject of at least one New Zealand case where a judge apparently refused a request from lawyers to abort a trial after internet research revealed a relationship between a juror and a witness. ${ }^{9}$ The Law Commission has indicated that it will investigate issues surrounding lawyers researching jurors in a review of the law of contempt. ${ }^{10}$

The courts and Parliament have been concerned to prevent the use of technology in a manner that undermines the right to a fair trial. For example, in $P v R$ the use of the internet to research a juror by a convicted defendant was held to be "entirely inappropriate and unacceptable". ${ }^{11}$ Likewise, a juror who conducts his or her own research on a case may be held to be in contempt of court. This article argues that, in contrast, pretrial research of jurors by lawyers with a view to peremptory challenge could serve to ensure, rather than undermine, a fair trial for all parties involved in a proceeding. It is not suggested that the practice would result in the perfect exercise of the peremptory right in every case, but it is argued that limited research by lawyers on prospective jurors could secure a more impartial jury and remedy the disparity of resources between the prosecution and defence by providing lawyers with an independent vehicle to obtain information about prospective jurors.

The first part of this article will briefly outline the jury selection process and the peremptory challenge. The past, present and possible future basis for the exercise of peremptory challenges will then be addressed. The main body of the article will discuss the benefits and possible drawbacks of pretrial research of prospective jurors with a view to peremptory challenge. Before concluding, draft guidelines for lawyers in conducting research of prospective jurors will be recommended.

7 At [14].

8 At [20].

9 Edward Gay "Lawyers Googling of Jurors to Come Under Scrutiny" The New Zealand Herald (online ed, Auckland, 23 January 2013).

10 Gay, above $\mathrm{n}$ 9. The Law Commission is currently undertaking a first principles review of the law of contempt of court. An issues paper is due to be published in 2014: Law Commission "Review of Contempt of Court" (11 April 2013) <www.lawcom.govt.nz>.

$11 P \vee R$, above $\mathrm{n} 1$, at [21] 


\section{THE JURY SELECTION PROCESS}

Before delving into the merits and drawbacks of pretrial research of jurors by lawyers it is necessary to outline the statutory framework that the peremptory challenge operates within and the primary rationales behind its exercise. With certain exceptions contained in the Juries Act 1981, any person between the ages of 20 and 65 years who is currently registered as an elector is eligible for jury service. ${ }^{12}$ When a jury panel is required, the registrar of the relevant court randomly draws names from the jury list and those that are picked are summoned to court. ${ }^{13}$ Any person sentenced to imprisonment for a term of three or more years, or to preventive detention, is disqualified from serving on a jury, ${ }^{14}$ as is any one who, in the preceding five years, has been sentenced to imprisonment for three or more months. ${ }^{15}$ Persons occupying certain positions at the time of summons such as ministers, judges and practising barristers and solicitors are also disqualified from serving on a jury. ${ }^{16}$

Section 14(1) of the Juries Act provides that an eligible person may apply to the registrar of the court to have the jury panel list made available for examination up to seven days before the trial date. Only the names of the prospective jurors are contained on the jury panel list. ${ }^{17}$ However, the registrar of the relevant court must comply with the request of certain eligible persons to make available a copy of protected particulars excluded from the jury panel list. ${ }^{18}$ Protected particulars include the address, occupation and date of birth of prospective jurors. ${ }^{19}$ In the absence of internet research of a prospective juror, the information contained on the jury panel list often informs the exercise of peremptory challenge.

12 Section 6.

13 Section 13

14 Section $7(a)$.

15 Section 7(b).

16 Section 8.

17 Section 13(1A) of the Juries Act 1981 was inserted by s 16 of the Juries (Jury Service and Protection of Particulars of Jury List Information) Amendment Act 2012 on 29 April 2013.

18 Section $14 \mathrm{AB}$ of the Juries Act 1981 provides that only certain "eligible persons", as listed in s 14(AB)(2), may apply to the registrar of the court to inspect a prospective juror's protected particulars. An "eligible person" means a barrister or solicitor acting for a party to the proceedings due to be heard, or a barrister or solicitor appointed for the purpose of inspecting protected particulars and exercising rights of challenge for a litigant in person, the Crown or prosecutor in criminal proceedings, or a Police employee acting in the course of their employment.

19 The Juries Amendment Act 2008, which came into force on 25 December 2008, amended the principal Act by removing the prohibition of jurors' dates of birth being referred to on the jury list. 
When potential jurors arrive at court, the balloting process takes place. If a potential juror's card is drawn out of the ballot box, ${ }^{20}$ their name is read out and they must make their way to their seat in the jury box. ${ }^{21}$ It is at this point that challenges may be made. A juror who is successfully challenged before sitting down must stand down and are excluded from taking any further part in the trial. $^{22}$

There are three different types of challenges: challenges for want of qualification, challenge for cause and the peremptory challenge, with which this article is primarily concerned. Section 23 of the Juries Act provides that a juror may be challenged and discharged if they fail to qualify under section 6, or if they are disqualified from serving on the jury under ss 7 or 8 . Each party is entitled to an unlimited number of challenges for cause on the ground that a juror is not indifferent between the parties or is incapable of discharging their role as a juror due to disability. ${ }^{23}$ However, the use of challenge for cause in New Zealand has been rare. One senior judge suggested the infrequency of challenges for cause was a result of the need to prove something that is "damning" to the person being challenged and the subsequent risk of such a challenge being unsuccessful. ${ }^{24}$

In contrast to challenges for cause, peremptory challenges are often used in New Zealand. Trial by Peers, a seminal study into the composition of New Zealand juries, reported that prosecution and defence counsel peremptorily challenged 36.5 per cent of balloted jurors. ${ }^{25}$ Section 24(1) of the Juries Act provides that each party is entitled to exercise four peremptory challenges against potential jurors. ${ }^{26}$ In a criminal case involving two or more accused persons, the prosecution is entitled to a maximum of eight peremptory challenges. ${ }^{27}$

20 Jury Rules 1990, r 15

21 Jury Rules 1990, r 19.

22 S Dunstan, J Paulin and KA Atkinson Trial by Peers?: The Composition of New Zealand Juries (Department of Justice, Wellington, 1995) [Trial by Peers] at 55.

23 Juries Act 1981, s 25.

24 Law Commission Juries in Criminal Trials (NZLC R69, 2001) [Juries In Criminal Trials] at [227]. See Sir Graham Speight "Submission to the Law Commission on Juries in Criminal Trials".

25 Trial by Peers, above n 22, at 56. In contrast, the use of the peremptory challenge in England was relatively rare before it was abolished in 1989. See Morris B Hoffman "Peremptory Challenges Should be Abolished: A Trial Judge's Perspective" (1997) 64 U Chi L Rev 809 for an in-depth analysis of the history of the peremptory challenge.

26 Section 17 of the Juries Amendment Act 2008 reduced the number of peremptory challenges available to each party from six to four.

27 Juries Act 1981, s 24(2) 
In its report Juries in Criminal Trials, the Law Commission outlined two primary rationales for the peremptory challenge. First, the peremptory challenge is said to secure an impartial jury by providing an efficient mechanism for removing jurors where the defence or prosecution have doubts as to their impartiality short of justifying challenge for cause. ${ }^{28}$ Proponents of the peremptory challenge claim that allowing each side to remove jurors they believe to be partial towards their case enables extremes of the jury pool to be eliminated on both sides. ${ }^{29}$ What is left is a jury composed of the "moderate middle". ${ }^{30}$

However, in practice the function of peremptory challenges in removing biased jurors is largely circumvented, as usually the objective of counsel is to secure a jury favourable to their client by retaining jurors who may be biased towards their case. ${ }^{31}$ Further, the limited information available about prospective jurors means the prospect of discerning any actual or potential impartiality on the part of jurors is unlikely. Prosecution and defence counsel are therefore forced to exercise the right to peremptory challenge based on stereotypes and assumptions. Thus it seems that the role of peremptory challenge in obtaining an impartial jury is largely symbolic.

The second rationale for peremptory challenge is that it gives the defendant a measure of control over the composition of the jury by allowing the defence to exclude prospective jurors perceived, rightly or wrongly, to be biased against the defence. ${ }^{32}$ Proponents of peremptory challenge argue that this results in greater acceptance of the jury's verdict as fair by the defendant and the wider public. ${ }^{33}$ The peremptory challenge is therefore one mechanism by which justice "can be seen to be done". ${ }^{34}$ The Law Commission highlighted the fact that the removal of the right to peremptory challenge may reduce the confidence of the defendant in the validity of the jury's verdict, leaving the system open to criticism. ${ }^{35}$ Evidently, the appellant in $P \vee R$ said that an indication to his trial lawyer that he wished to challenge the particular juror during empaneling was ignored. ${ }^{36}$ This failure formed the basis of the appeal against the jury's verdict.

28 Juries in Criminal Trials, above n 24, at [218].

29 Roger Allan Ford "Modelling the Effects of Peremptory Challenges on Jury Selection and Jury Verdicts" (2010) 17 Geo Mason Law Rev 377 at 377.

30 At 377

31 Law Commission Juries in Criminal Trials Part One (NZLC PP32, 1998) [Juries in Criminal Trials Part One] at [392].

32 Juries in Criminal Trials, above n 24, at [218].

33 Juries in Criminal Trials, above n 24, at [218].

$34 R v$ Sussex Justices; Ex parte McCarthy [1924] 1 KB 256 at 259.

35 Juries in Criminal Trials Part One, above n 31, at [393].

$36 \quad P \vee R$, above $\mathrm{n} 1$, at footnote 7 . 
Whether or not the peremptory challenge meets its purported rationales has been the subject of debate. ${ }^{37}$ The inclination of other jurisdictions has been to remove the peremptory right. ${ }^{38}$ England and Wales abolished the right of peremptory challenge in $1988 .{ }^{39}$ After an extensive review, the Law Commission recommended the retention of the peremptory challenge, ${ }^{40}$ despite conceding that it could not demonstrate whether the exercise of the challenge meets its claimed rationales. ${ }^{41}$

It is argued that allowing lawyers to garner more information about prospective jurors through the internet would allow them to find actual or perceived biases, enabling the peremptory challenge to fulfil its purported rationale of securing an impartial jury. Rather than playing a solely symbolic role, a more informed exercise of the peremptory right would increase the confidence of the defendant in the fairness of the jury's final verdict. The next part of this article will discuss the exercise of peremptory challenge absent research by lawyers and highlight new technology that could enable lawyers to exercise the peremptory right on a more sound evidential basis.

\section{LAWYERS RESEARCHING JURORS: PAST, CURRENT AND POSSIBLE FUTURE PRACTICE}

\section{A Past Practice}

In the New Zealand context, there is little historical evidence of lawyers researching jurors, though there has been some suggestion of an emerging trial consulting industry. ${ }^{42}$ Several psychologists were reported to be advising counsel on who to challenge using information gathered through the observation of the jury pool, public records and credit checks. ${ }^{43}$ That said, it is unclear how common the practice is in New Zealand.

In contrast, researching prospective jurors in the United States is undertaken extensively. ${ }^{44}$ Dissatisfied with the limited information available from the court, attorneys began investigating prospective jurors in the early 20th century. ${ }^{45}$ Public and private investigators were hired to aid in

37 See Hoffman, above n 25.

38 Juries in Criminal Trials Part One, above n 31, at [365].

39 Section 118(1) of the Criminal Justice Act 1988 (UK) provides that "the right to challenge jurors without cause in proceedings for the trial of a person on indictment is abolished".

40 Juries in Criminal Trials, above n 24, at [229].

41 Juries in Criminal Trials Part One, above n 31, at [397].

42 Juries in Criminal Trials, above n 24, at [249]-[250].

43 At [250].

44 Thaddeus Hoffmeister "Investigating Jurors in the Digital Age: One Click at a Time" (2012) 60 U Kan L Rev 611 at 615.

45 At 616 
the selection of a jury. Information gathering methods ranged from researching public archives to more intrusive methods such as "drive-bys" of the juror's house, speaking with the juror's neighbours or following the juror. ${ }^{46}$ Such investigations gave insight into a juror's socio-economic background, opinions and personal habits, providing invaluable information for attorneys looking to challenge potential jurors who had certain characteristics. ${ }^{47}$ "Trial consulting" in the United States has since developed into a completely unregulated, multi-million dollar industry.

\section{B The Basis upon which Peremptory Challenges are Currently Exercised}

Currently, three main sources of information form the basis for the exclusion of potential jurors through peremptory challenge:

- The information provided on the jury panel list and protected particulars including the name, address, occupation and date of birth of prospective jurors.

- $\quad$ The appearance and general demeanour of prospective jurors.

- $\quad$ Police vetted jury panel lists; a resource which is exclusive to the prosecution.

Research conducted into the composition of juries in New Zealand found that the address of a potential juror was often a deciding factor in whether they would be peremptorily challenged. ${ }^{48}$ Both prosecution and defence counsel felt that addresses served as an indicator of the views or prejudices a potential juror may hold. Those from a middle-class background were assumed to be more likely to hold a bias against perpetrators of certain types of offending, such as burglary, as they felt particularly vulnerable to it. ${ }^{49}$ Thus the defence invariably challenged such people. Prosecution counsel were likely to challenge people from areas that were thought to have "sympathies with the accused or the groups that the accused may be from". ${ }^{50}$

Similarly, potential jurors in certain occupations were more likely to be challenged. Prejudice against school teachers and law students was a common thread from both prosecution and defence counsel in the Trial by Peers report, the assumption being that they were likely to cause hung juries by "holding out" or by trying to swing the vote. ${ }^{51}$ As will be discussed in more depth further on,

46 At 618.

47 At 618.

48 Trial by Peers, above n 22, at 115.

49 At 116 .

50 At 116

51 At 118. 
ethnicity also appeared to play a large role in the decision to exercise a peremptory challenge. Māori men, in particular, have been under-represented on juries as a result of peremptory challenges. ${ }^{52}$

The overall appearance and demeanour of potential jurors was another aspect informing the exercise of the peremptory challenge. As aptly put by one counsel: "You look at the way they dress, at the way they walk... [It's] all pure prejudice". ${ }^{53}$ Prosecution counsel had a tendency to challenge those who dressed "roughly" and were perceived to be more "liberal", while defence counsel challenged those who appeared "conservative", assuming them to be biased against the accused. ${ }^{54}$

As concluded in Trial by Peers, counsel tend to "make assumptions of bias and use catch-all categories" when exercising the peremptory challenge. ${ }^{55}$ Counsel recognise that assumptions based on the limited information they receive regarding prospective jurors can be quite wrong, but in the absence of further information they are forced to exercise challenges on such a basis. ${ }^{56}$

In addition to the basic personal details from the jury panel list and protected particulars, and the overall appearance of jurors, information gathered through jury vetting (checking the backgrounds of potential jurors) is sometimes used as a foundation for the exercise of peremptory challenges. Typically the police assist prosecution counsel by annotating a copy of the jury panel list with any previous non-disqualifying criminal convictions. In some instances, particularly in smaller districts, the police will note any names on the list that they recognise or any known criminal gang connections. ${ }^{57}$

However, the scope for vetting by defence counsel is limited, and in Trial by Peers it was confirmed that vetting by defence counsel was infrequent. ${ }^{58}$ Most showed the jury list to their client to see whether there was anyone they knew or wanted to challenge. ${ }^{59}$ In smaller districts, some defence counsel showed the list to other staff solicitors to gather information on potential jurors but it was noted that this was of little use in larger districts where personal knowledge of potential jurors

52 At 57. The Solicitor-General, in response to these findings, issued an instruction to Crown solicitors stating that they should take whatever steps necessary to ensure that Māori men are not disproportionately challenged.

53 At 122 .

54 At $121-122$.

55 At 129

56 At 129.

57 Aysser Al-Janabi "A Study of Variations in Jury Vetting Practices Across New Zealand" (LLB (Hons) Dissertation, Victoria University of Wellington, 2011) at 13.

58 Trial by Peers, above n 22, at 108.

59 At 108. 
was less likely. ${ }^{60}$ Otherwise defence counsel "rely heavily on their intuition, experience and [judgement]" when making peremptory challenges. ${ }^{61}$

The disparity between prosecution and defence in terms of their ability to obtain information about prospective jurors has caused some concern in relation to the potential imbalance of power it creates. As well as variations between prosecution and defence vetting practices, there are significant differences in jury vetting across districts. Although police vetting of jury lists occurs in all major High Court districts, with the exception of Auckland the extent of the information garnered varies. ${ }^{62}$ The use of the internet to conduct pretrial research on jurors has the potential to significantly decrease the disparity between prosecution and defence resources.

\section{Possibilities for Future Practice}

As can be seen, lawyers peremptorily challenge jurors in a discriminatory fashion, not by choice, but due to a lack of information on which an informed decision can be made. However, the digital age has the potential to transform New Zealand lawyers into "amateur jury consultants". With the increased digital footprint of prospective jurors, lawyers now have a "treasure trove" of personal information at their fingertips. ${ }^{63}$ Public records are now available online. Social media sites such as Facebook and Twitter may be used to discover prospective jurors' religious views or expose any prejudices. The professional networking site LinkedIn may be used to uncover any business connections to a competitor of a party to the case. ${ }^{64}$ A simple Google search may expose any links a prospective juror has to particular political organisations.

In the United States, the advent of the internet has streamlined the jury research process by allowing attorneys to conduct their own investigation of potential jurors, without having to use expensive jury consultants. Pretrial research of prospective jurors by lawyers has become routine. ${ }^{65}$ Some practitioners argue that internet research into the personal backgrounds of potential jurors is necessary to fulfil the lawyer's professional duty of competence and due diligence. ${ }^{66}$ Courts in a number of states facilitate this practice by providing attorneys with information on prospective

60 At 108.

61 Gordon-Smith v R [2009] NZSC 20 at [27].

62 Regular police vetting of jury panel lists ceased in 1983. Police vetting is now only used in particularly contentious cases. See Al-Janabi, above n 57, at 7-8.

63 Duncan Stark "Juror Investigation: Is In-Courtroom Internet Research Going to Far?" (2011) 7 Wash JL Tech \& Arts 93 at 98

64 At 98.

65 Hoffmeister, above n 44, at 612.

66 Stark, above n 63, at 97. 
jurors weeks in advance of the jury selection process. ${ }^{67}$ Thus pretrial internet research of prospective jurors appears to be largely accepted in the United States, though some consider the practice raises ethical issues. ${ }^{6}$

Although the internet is not always a reliable source of information, the nature of the peremptory challenge as a challenge without cause necessarily permits some lack of accuracy. As was noted earlier, it is not suggested that internet research will result in the perfect exercise of the peremptory right in every case, simply that it will provide an alternative to reliance on discriminatory stereotypes. In many instances this will result in the empanelling of a more impartial jury as the internet provides counsel with a means to uncover actual or perceived bias in prospective jurors.

In the following parts, the benefits of exercising the peremptory challenge on a more informed basis will be discussed and drawbacks of the practice will be addressed.

\section{PROSPECTIVE JURORS ON TRIAL: THE BENEFITS}

\section{A A More Impartial Jury}

The primary justification for the exercise of peremptory challenge is the empanelment of an impartial jury. However, in the absence of any information on the personal attitudes and backgrounds of potential jurors, the peremptory challenge pays only lip service to the fundamental right of every citizen to a fair hearing by an independent and impartial court. ${ }^{69}$ Pretrial research by lawyers with a view to challenge can help ensure a more impartial jury in two ways: first, by providing more information about the backgrounds and attitudes of prospective jurors, and secondly by ensuring an equality of resources between prosecution and defence.

The internet can be used by lawyers as a tool to garner more information about prospective jurors, allowing them to uncover attitudinal biases or predispositions that may affect the impartiality of prospective jurors. Vidmar's typology outlines four categories of bias, three of which highlight how pretrial internet research could uncover otherwise invisible bias: ${ }^{70}$

- $\quad$ interest prejudice: where a juror has a direct interest in the outcome of the case;

- $\quad$ specific prejudice: where attitudes or beliefs held by a juror in relation to a particular case or party might render them incapable of deciding the case in an impartial manner; and

67 Adam J Hoskins "Armchair Jury Consultants: The Legal Implications and Benefits of Online Research of Prospective Jurors in the Facebook Era" (2012) 60 Minn L Rev 1100 at 1101.

68 At 1101.

69 New Zealand Bill of Rights Act 1990, s 25(1)(a).

70 Neil Vidmar "A Historical and Comparative Perspective on the Common Law Jury" in Neil Vidmar (ed) World Jury Systems (Oxford University Press, New York, 2000) 1 at 32. 
- $\quad$ generic prejudice: where a juror stereotypes a defendant, victim, witness or type of crime.

Judging a prospective juror on the basis of their appearance, occupation, address or any other broad stereotype is unlikely to uncover bias. For example, a relationship between a potential juror and a witness (or an "interest bias") is unlikely to be uncovered by merely looking at the potential juror. Likewise, a specific prejudice on part of a juror will not usually be evident by simply looking at their particulars. As in the case of $P v R$, looking at a prospective juror's Facebook profile may reveal that a juror has an attitudinal bias against adults who indecently assault children (a "specific prejudice"). ${ }^{71}$ Though this is not necessarily indicative of actual bias, as what people say in the abstract and what they do in specific situations may differ, at the very least it gives rise to a perceived bias. Pretrial research of prospective jurors may uncover such biases and, as a corollary, prevent questions arising about a juror's impartiality after a trial has finished.

Pretrial research may also go some way to remedying the disparity between the resources available to prosecution and defence counsel. The assumption in the adversarial context is that each side will exclude potential jurors who are most favourable to the other side, resulting in an impartial jury. The problem with this assumption is that it assumes equality of resources between each side. ${ }^{72}$ As Hoffmeister has highlighted, the government has traditionally held an advantage over the defence because it has the ability to access information not readily accessible to the wider public. ${ }^{73}$ In the New Zealand context, there is often a significant disparity between the information provided to the Crown through police vetting and the limited information available to the defence. ${ }^{74}$ This inequality of resources can lead to differing levels of preparation for trial and can ultimately lead to an unfair trial. ${ }^{75}$

The courts have recently compounded the disparity between prosecution and defence resources. In Australia, legislation has affirmed a High Court decision holding that the police vetting of jury panel lists for non-disqualifying convictions is unlawful. ${ }^{76}$ However, the New Zealand Supreme Court has recently affirmed the legality of the practice in Gordon-Smith $v R .{ }^{77}$ The first question on

$71 \quad P \vee R$, above $\mathrm{n} 1$, at [13]. Statements found by the defendant on the juror's Facebook page included criticisms of sentences passed down on defendants in previous cases with similar facts.

72 Franklin Strier and Donna Shestowsky "Profiling the Profilers: A Study of the Trial Consulting Profession, Its Impact on Trial Justice and What, If Anything, To Do About It" (1999) Wis L Rev 441 at 475.

73 Hoffmeister, above n 44, at 616.

74 Trial by Peers, above n 22, at 105-113.

75 Hoskins, above n 67, at 1101. See also Strier and Shestowsky, above n 72, at 475.

76 The Juries Act 2000 (Vic) affirmed the decision of the High Court of Australia in Katsuno v R [1999] 199 CLR 40, which held that the Commissioner of Police did not have power to investigate and pass on to the Director for Public Prosecutions information regarding non-disqualifying convictions of potential jurors.

77 Gordon-Smith $v$ R, above $\mathrm{n} 61$. 
appeal was whether the police could lawfully obtain information about the criminal history of prospective jurors. The majority of the Court confirmed the finding of the Court of Appeal, holding that the police vetting of prospective jurors was lawful. On the second question, whether the Crown should provide such information to the defence, the majority held that the Crown was not permitted or required to disclose any previous convictions of potential jurors to the defence. An exception applies where the previous conviction "gives rise to a real risk that the juror might be prejudiced against the accused or in favour of the Crown". ${ }^{78}$

McGrath J concurred with the majority of the Court regarding the legality of the practice of police vetting. However, on the question of whether the Crown was required to disclose vetted information to the defence, McGrath $\mathrm{J}$ gave a lengthy dissent, concluding that the Crown should provide the defence with all information about a potential juror that may be relevant to that juror's suitability to serve. ${ }^{79}$ McGrath J's position is similar to that in Canadian law where the prosecution must disclose all previous convictions of any prospective juror to the defence. ${ }^{80}$

Ensuring an equality of arms between defence and prosecution counsel is an important consideration given the decision of the majority in Gordon-Smith $v R$, which removes the opportunity of defence counsel to benefit from police vetting practices. The exception to nondisclosure is limited to situations involving a "real risk of prejudice". However, even the slightest risk of prejudice may affect the fundamental right to trial by an independent and impartial jury. The internet gives defence counsel in particular an independent vehicle to get information about prospective jurors. Internet research has the potential to level the "playing field" as information on the internet is free, easily accessible and available to all.

Pretrial internet research has arguably become more important given the time and funding restrictions placed on criminal defence lawyers by changes to the legal aid system in 2012. The changes introduced a fixed fee system whereby lawyers are paid based on the seriousness of the charges facing their client instead of the hours they spend on their client's case. ${ }^{81}$ It is yet to be seen whether lawyers will have the time or inclination to conduct internet research on prospective jurors in light of the funding restraints. The use of the internet to research prospective jurors may vary according to the type of case at hand, with greater time being spent on more serious or high profile cases which, by reason of trial complexity, are entitled to greater legal aid funding. Lawyers may be

78 At [22].

79 At [89] per McGrath J.

$80 R v$ Emms (2010) 264 CCC (3d) 402 (Ont CA) at [47].

81 See Gordon Campbell "Shedding Light on Legal Aid Changes" Dominion Post (online ed, Wellington, 27 March 2013). The Court of Appeal recently ruled that the Government's policy in relation to legal aid funding is unlawful in Criminal Bar Association of New Zealand Inc v Attorney-General [2013] NZCA 176. 
less inclined to give the same treatment to more straightforward cases due to time and funding constraints. However, given the speed and ease of access to the internet, pretrial research is unlikely to significantly increase the workload of lawyers and can provide a fast and effective means of uncovering actual or perceived bias.

\section{B A More Representative Jury}

The legitimacy of the jury lies in its democratic nature - all groups in the community should be represented in the composition of the jury. ${ }^{82}$ The "diversity of knowledge, perspectives and personal experiences" reflected in a representative jury "enhances the collective competency of the jury as fact-finder" and conscience of the community. ${ }^{83}$ As Gonthier $\mathrm{J}$ noted in $R \vee$ Biddle, though "representativeness" is not an essential quality of the jury, it is "a characteristic which furthers the perception of impartiality" and is therefore a trait that should be "sought after". ${ }^{84}$

As reported in Trial by Peers, the representation of different groups has been negatively impacted by the use of peremptory challenges. ${ }^{85}$ In particular, peremptory challenges have been used to exclude a disproportionate percentage of prospective Māori jurors. ${ }^{86}$ This lack of representation can in itself result in a type of bias. ${ }^{87}$ Indeed, the impetus for the Trial by Peers study was a 1988 report by Moana Jackson, which expressed concern at the "monocultural bias" in the New Zealand jury, partly due to the exercise of peremptory challenges. ${ }^{88}$ The question is whether the representativeness of the jury can be improved through the intelligent exercise of peremptory challenges.

Prosecution counsel interviewed in Trial by Peers indicated that a Māori potential juror was more likely to be challenged if the accused was also Māori. This increased likelihood of challenge was based on the assumption that a Māori juror would be more sympathetic towards a Māori defendant, in which case a trial by "cultural or racial peers" was perceived to entail an element of bias towards the defendant. ${ }^{89}$ This perception was compounded where the Māori juror and the Māori accused shared a similar appearance. Further, a higher rate of convictions among Māori men informed the view that they were likely to be "anti-police" and therefore biased against the Crown

82 Juries in Criminal Trials, above n 24, at [133].

83 At [133].

$84 R v$ Biddle (1995) 96 CCC (3d) 321 (SCC) at [53].

85 Juries in Criminal Trials Part One, above n 31, at [392].

86 Trial by Peers, above n 22 at 33.

87 Juries in Criminal Trials Part One, above n 31 at [392].

88 Moana Jackson He Whaipaanga Hou: Māori and the Criminal Justice System - A New Perspective (Department of Justice, Wellington, 1988) at 139.

89 Juries in Criminal Trials Part One, above n 31, at [386]. 
case, contributing to the disproportionate challenge rate. ${ }^{90}$ Adding to these considerations was the fact that Māori tended to be from lower socioeconomic groups, which the prosecution were inclined to challenge. ${ }^{91}$

As can be seen, peremptory challenges are exercised not on the basis of actual or potential bias but instead on unsubstantiated assumptions and prejudices. In the absence of information as to a potential juror's personal background and possible attitudinal biases, counsel are forced to exercise peremptory challenges on these discriminatory bases. For many Māori defendants, juries are therefore not representative of their community or their values - Māori defendants are not tried by their peers. ${ }^{92}$ Online research of potential jurors may enable counsel to judge a potential juror's impartiality by reference to facts rather than his or her ethnicity.

However, it must be highlighted that online research of prospective jurors is not a fix-all solution that will remove all prejudices entrenched over the years. There is a risk that additional information will simply compound prejudice. Although the evidence-based exercise of peremptory challenge could go some way to avoid the disproportionate exclusion of Māori from juries, it is unlikely to significantly impact on the representativeness of the jury. As the Law Commission noted, there are other factors contributing to the under-representation of Māori on the jury which must be addressed. ${ }^{93}$ Namely, Māori are more likely than Pākehā to have a disqualifying conviction under $\mathrm{s} 7$ of the Juries Act. Further, non-disqualifying convictions may form the basis of a challenge by the prosecution if they indicate a potential bias against the prosecution or the police. ${ }^{94}$ Māori are also more likely to face barriers to jury service, such as lack of adequate child-care facilities or transport. ${ }^{95}$

\section{Increased Confidence of the Defendant and the Wider Public in the Verdict of the Jury as Fair}

Although the effect of the evidence-based exercise of peremptory challenges on the representativeness of the jury is limited, it may give the defendant greater confidence in the jury and its verdict. As noted earlier, the peremptory challenge system can be supportive of the fair trial right

90 Trial by Peers, above n 22, at 132.

91 Trial by Peers, above n 22, at 136.

92 Khylee Quince "Māori and the Criminal Justice System in New Zealand" in J Tolmie and W Brookbanks (eds) Criminal Justice in New Zealand (LexisNexis, Auckland, 2007) 333 at [12.3.3].

93 Juries in Criminal Trials, above n 24, at [228].

94 Juries in Criminal Trials, above n 24, at [216].

95 At [175]. 
as it is one means by which justice "can be seen to be done". ${ }^{96}$ The fact that the role the peremptory challenge plays in this sense is symbolic does not diminish its importance.

The case of $P \vee R$ provides a poignant example of a defendant's lack of confidence in the jury as a result of perceived bias. ${ }^{97}$ Arguably, had pretrial research been conducted, the comments of the juror in question would have been discovered before the trial and the juror could have been challenged. The defendant's appeal on the basis of juror partiality would have been avoided, saving both time and money. While the juror may not have been operating under any actual bias, it is important to take into account the perception of the defendant and the wider public. It is likely a reasonable observer would have doubted the impartiality of the juror in question in light of the statements found on her Facebook page.

Further, the disparity between the resources of the Crown and the defence noted earlier is likely to cause concern for defendants and the wider public. As highlighted by McGrath J in Gordon-Smith $v R$, a reasonable observer of the jury trial process would be likely to conclude that the Crown has a significant advantage over the defence in securing a jury. ${ }^{98}$ Reducing disparity between Crown and defence resources not only improves the impartiality of the jury in fact, but it also improves the defendant's and wider public perceptions of impartiality.

\section{Lawyers Better Able to Fulfil Duty to Client}

In addition to securing a more impartial jury and increasing confidence in the jury's verdict, pretrial research of jurors may better assist practitioners with their overriding duty to the court and duty to act in the best interests of their clients. ${ }^{99}$ In the United States, internet research is used by parties in order to gain a "competitive edge" over their opposition. ${ }^{100}$ Some suggest that not conducting pretrial research amounts to malpractice and a failure to "zealously advocate" the best interests of the client. ${ }^{101}$ Courts and bar associations across the United States have endorsed the practice. In 2011, the New York County Lawyers Association released an opinion stating, "it is proper and ethical ... for a lawyer to undertake a pretrial search of a prospective juror's social networking site, provided there is no contact or communication with the prospective juror". ${ }^{102}$

$96 R v$ Sussex Justices; Ex parte McCarthy, above n 34, at 259.

$97 P \vee R$, above $\mathrm{n} 1$.

98 Gordon-Smith $v$ R, above n 61, at [77].

99 Lawyers and Conveyancers Act 2006, s 4.

100 Hoskins, above n 67, at 1108.

101 At 1108 .

102 New York County Lawyers Association "Committee on Professional Ethics Formal Opinion No 743" (18 May 2011). 
Further, the decision of the Missouri Supreme Court in Johnson v McCullough appears to place a burden on lawyers to examine and provide the court with a prospective juror's litigation history prior to trial. ${ }^{103}$ The case concerned a medical negligence lawsuit brought by a patient against a physician. Research into a particular juror after the jury had returned a verdict in favour of the defendant revealed that the juror had not disclosed their civil litigation history during voir dire. A new trial was ordered on the basis that the non-disclosure was prejudicial.

Arguably, pretrial research on the part of the trial lawyer in $P v R$ would have better served the interests of the defendant and the lawyer's overriding duty to the court. Though not suggesting that the foreperson of the jury was actually biased against the defendant, had the trial lawyer discovered the comments on the juror's Facebook page, the juror could have been challenged before the trial began, saving a costly appeal process.

\section{PROSPECTIVE JURORS ON TRIAL: ADDRESSING FEARS}

\section{A Privacy and Perceptions of Potential Jurors ${ }^{104}$}

One criticism of the practice of lawyers researching prospective jurors with a view to peremptory challenge is the risk of encroaching on the privacy of jurors. As noted by academics and commentators across jurisdictions, the term "privacy" is notoriously hard to define. ${ }^{105}$ The concept of privacy in New Zealand is still in the course of development and consequently the law in the area of privacy is rather unsettled. Though the Court of Appeal in New Zealand has accepted that there is a tort of privacy in New Zealand, ${ }^{106}$ there is no express guarantee of a right to privacy in legislation. ${ }^{107}$ This article is solely concerned with what can be termed "informational privacy", which encompasses the control of, and access to, personal information. ${ }^{108}$ This could include the

103 Johnson v McCullough 306 SW 3d 551 (MO 2010) at 559. See also discussion of the case in Hoffmeister, above n 44, at 627-628; and Correy Stephenson "Should Lawyers Monitor Jurors Online?" (27 December 2010) LegalNews.com <www.legalnews.com>.

104 For a detailed and thorough discussion of privacy law in New Zealand, see Stephen Penk and Rosemary Tobin (eds) Privacy Law in New Zealand (Brookers, Wellington, 2010).

105 See Law Commission Privacy Concepts and Issues: Review of the Law of Privacy Stage 1 (NZLC SP19, 2008) [Privacy Concepts and Issues] at 10.

106 Hosking v Runting [2004] NZCA 34.

107 A right to privacy was not included in the New Zealand Bill of Rights Act 1990, although privacy considerations can arise under s 5 as a justifiable limitation on rights contained in the Act, or under s 21 in relation to the right to be protected from unreasonable search and seizure. See Privacy Concepts and Issues, above n 103, at 15 and 90-95. The Privacy Act 1993, while not conferring a legally enforceable right to privacy, provides a mechanism whereby individuals can lay a complaint alleging an invasion of their privacy under s 67.

108 Privacy Concepts and Issues, above n 105, at [2.14]. 
ability to control the use to which personal information is put once disclosed. ${ }^{109}$ The rapid advancement of the internet and associated technologies has had a notable impact on informational privacy, particularly in relation to the availability of personal information published online by private individuals. ${ }^{110}$

An argument against allowing lawyers to research prospective jurors is that it will amount to an undue interference with informational privacy. However, it is important to highlight that "personal information" is not synonymous with "private information". ${ }^{111}$ Information placed on the internet by a prospective juror may be personal, but once it is published online it is no longer private. The prospective juror no longer has control over the personal information. It is arguable whether the access to that information by lawyers with a view to challenge is any different in principle to the access to that information by employers or landlords. ${ }^{112}$ That said, instances where information about a prospective juror is posted on the internet without their consent by a third party may give rise to a greater privacy concern. ${ }^{113}$

To prevent any undue interference with the privacy interests of prospective jurors, it is recommended that guidelines governing the conduct of research be put in place. Among other things, the guidelines should include a safeguard limiting the scope of counsel research to information that is publicly available. Allowing lawyers to go through private information on a person's Facebook page that can only be viewed by "friends" of the person would be an undue interference with privacy. Likewise, "friending" of a prospective juror on Facebook by a lawyer in order to access information on their page, sending them tweets, or otherwise attempting to contact prospective jurors would overstep appropriate degrees of separation between counsel and jurors. ${ }^{114}$ In some instances, this may mean that access to information is limited, but such a limit is necessary to protect the privacy of prospective jurors and the integrity of the jury system.

Pretrial internet research of prospective jurors pales in comparison with other methods of jury screening which may constitute a significant interference with their privacy interests. As noted earlier, the research of jurors in the United States can include practices bordering on stalking. Prospective jurors are then subjected to public questioning, which may include intensely personal

109 At [2.18].

110 At 18.

111 At 18.

112 Hoffmeister, above n 44, at 638-639. There has been some recent controversy surrounding employers' access to prospective employees social media sites. See Deborah Doak and Nicki Donnelly "Facebook - fair game for prospective employers?" (27 April 2012) Bell Gully <www.bellgully.com>.

113 Privacy Concepts and Issues, above n 105, at [6.33].

114 New York County Lawyers Association, above n 102, at 1. 
enquiries. Online research of prospective jurors is a lot less invasive than other alternatives. ${ }^{115}$ It could be argued that condoning research by counsel on prospective jurors in the way proposed may give way to more intrusive measures being accepted further down the track. However, such a fear may be addressed through the proposed guidelines that will focus on the acceptable use of the internet to research prospective jurors.

The practice of lawyers researching jurors pretrial may not significantly affect juror privacy interests in fact. However, juror perception of the practice and the extent to which it is perceived to interfere with privacy interests is an important consideration. As noted in $P \vee R$, "[jurors] are called on to perform a critical public service in the administration of justice". ${ }^{116}$ Some prospective jurors may be deterred from serving on the jury if they feel that it would entail an interference with their privacy. Any factor that may deter members of the public from serving on the jury threatens to undermine the integrity and representativeness of the jury system. ${ }^{117}$

There is a fear that deterrence of jurors from performing their civic duty will exacerbate the already low figures on jury attendance. In 2009, over 80 per cent of people summoned avoided jury service, either through excusal or by failing to show up. ${ }^{118}$ However, the introduction of a deferral system whereby summoned jurors may defer jury service to a more convenient time has had a positive impact on jury attendance. ${ }^{119}$ Figures obtained under an Official Information Act request show that, since the introduction of a deferral system in October 2010, jury attendance has improved. ${ }^{120}$

Measures included in the proposed guidelines for lawyers conducting online research could go some way to putting jurors at ease. For example, the guidelines could provide that jurors should be informed that research may be undertaken for the purpose of peremptory challenge, but that any information obtained will be used for that purpose only and kept entirely confidential.

\section{$B$ The Issue of Self-Represented Defendants}

Linked to privacy concerns and the perceptions of prospective jurors is the issue of the self-

115 Hoffmeister, above n 44, at 638.

$116 P \vee R$, above $\mathrm{n} 1$, at [14].

117 At [14].

118 Shelley Bridgeman "Have you avoided jury duty?" The New Zealand Herald (online ed, Auckland, 30 July 2012).

119 Section 14B of the Juries Act 1981 was inserted by s 11(1) of the Juries Amendment Act 2008 on 4 October 2010. The section gives the registrar power to permit a summoned juror to defer service to a time indicated to be more convenient.

120 Aaron Leaman "Courts target jury no-shows" Waikato Times (online ed, Hamilton, 17 June 2013). From July 2011 to December 2012, 82 per cent of jurors who deferred jury service under the new system appeared for jury service when re-summonsed. 
represented defendant. Trial proceedings involving self-represented defendants are an area of concern that must be addressed when defining the bounds of pretrial research. As highlighted in $P v$ $R$, the research into the personal backgrounds of jurors by a defendant is "entirely inappropriate and unacceptable". ${ }^{121}$ Such a practice would give rise to serious concerns regarding the safety of prospective jurors and would be likely to deter members of the public from serving on the jury. One can imagine the possible disastrous consequences were certain self-represented defendants given access to prospective jurors' particulars for the purpose of conducting pretrial research. Such concerns could be addressed by extending certain provisions of the Juries Act.

The availability of information about prospective jurors has been restricted significantly by Parliament out of concern for the privacy and safety of jurors. Section 13(1A) of the Juries Act was enacted in response to an incident in 2010 in which a convicted murderer contacted a juror whose name he saw on the jury panel list while representing himself at trial. ${ }^{122}$ The provision provides that only the names of prospective jurors are to be on the jury panel list. However, "litigants in person" are included among the list of "eligible persons" who may apply to the registrar of the court to have a copy of the jury panel list made available for inspection. ${ }^{123}$ Thus, self-represented defendants are eligible to inspect the jury panel list.

However, self-represented defendants are not eligible to inspect the protected particulars of prospective jurors which are excluded from the panel list under s 13(1A). As noted earlier, "protected particulars" contain the address, occupation and date of birth of prospective jurors. Instead, a barrister or solicitor may be appointed by the registrar to exercise rights of challenge for litigants in person under s 14AC(1) if they so wish. A barrister or solicitor appointed under s $14 \mathrm{AC}(1)$ may request, and exercise a challenge on the basis of, a copy of protected particulars under s $14 \mathrm{AB}(1)$. Section 14AC could be extended to protect prospective jurors in the case of selfrepresented defendants by allowing a barrister or solicitor to be appointed for the purpose of conducting research with a view to challenge. Such a solution would ensure that the defendant receives a fair trial while protecting the safety of prospective jurors.

\section{Reliance on Unauthenticated Information as Basis for Challenge}

The vast array of information on the internet is not necessarily validated or authenticated, but for many people today it is authoritative. If one wishes to know about something, one will simply "Google it". Researching the background of potential jurors with a view to challenge relies on two assumptions. First, such research assumes "it is the attitudes of jurors, not the evidence, which

$121 P \vee R$, above $\mathrm{n} 1$, at [21].

122 See Juries (Jury Service and Protection of Particulars of Jury List Information) Amendment Bill 2012 (2782); Judith Collins "New Law Protects Jurors, Improves Jury System" (press release, 29 April 2013).

123 Juries Act 1981, s 14(1A)(b). 
determine how a jury decides a case". ${ }^{124}$ Secondly, lawyers rely on the assumption that information obtained using online tools is accurate. Information gleaned from a prospective juror's Facebook profile or information about what organisations they belong to will not necessarily provide an accurate picture of the personal background or attitudinal biases which a prospective juror possesses. An internet search of an individual may yield limited information, leaving lawyers to fill in the informational gaps with assumptions.

Additionally, in the case of common names, lawyers run a risk of collecting information about the wrong person, rendering the whole process nugatory. Thus there is a danger in placing a heavy reliance of information obtained using the internet without any means of verification. Common sense dictates that lawyers conducting pretrial research on jurors keep in mind the potential for misinformation.

\section{A Challenge With or Without Cause?}

The practice of researching jurors with a view to challenge may be open to criticism in that the peremptory challenge is, by nature, a challenge without reason. It could be argued that through pretrial research, what was designed to be a challenge "without cause" would transform into a challenge "for cause". However, given the high threshold required to establish a challenge for cause, such a transformation is unlikely.

Under s 25 of the Juries Act, a successful challenge for cause requires that the juror in question "is not indifferent between the parties". The requirement of a lack of indifference sounds relatively easy to establish but in practice it is extremely difficult to substantiate. ${ }^{125}$ Prima facie, a reading of $\mathrm{s}$ 25 requires that a potential juror be biased in fact. Therefore a non-specific bias held by a potential juror is not a sufficient basis for a challenge for cause. ${ }^{126}$ For example, the Court of Appeal in $P \vee R$ held that the juror's communications did not prevent her from being indifferent between parties and thus would not have provided a basis to challenge for cause. ${ }^{127}$ Research by lawyers into the personal background of prospective jurors is unlikely to provide evidence sufficient to form the basis of a challenge for cause, but it may uncover non-specific biases or attitudes unfavourable to their case. Lawyers will then be able to exclude prospective jurors with unfavourable non-specific biases from the trial. Thus it is argued that peremptory challenges still play an important role in securing an impartial jury.

In sum, the practice of lawyers researching prospective jurors with a view to peremptory challenge may present some drawbacks. However, in light of the benefits the practice may bring, it

124 Lauren Rousseau "Privacy and Jury Selection: Does the Constitution Protect Prospective Jurors from Personally Intrusive Voir Dire Questions?" (2006) 3(2) Rutgers Journal of Law \& Urban Policy 287 at 298.

125 Juries in Criminal Trials Part One, above n 31, at [407].

126 At [407].

$127 P \vee R$, above $\mathrm{n} 1$, at [28]. 
is argued that these drawbacks are limited and can be addressed through the introduction of guidelines.

\section{GUIDELINES FOR RESEARCH ON JURORS}

It is argued that the justice system should embrace these new technologies and recognise that they are likely to be used by lawyers. Statutory regulation of the activity is an unrealistic option given the ease of access to the internet, which would make policing the practice difficult. Rather than attempt to suppress the practice of lawyers researching prospective jurors through prohibition, it is suggested that the best option is to incorporate guidelines into the Lawyers and Conveyancers Act (Lawyers: Conduct and Client Care) Rules 2008, to govern the use of the internet for the purpose of researching prospective jurors.

The guidelines proposed contain guidance for lawyers around the collection, use, retention and disclosure of information. The following guidelines are proposed.

Guidelines for the pretrial research of prospective jurors with a view to challenge

1 Proper purpose of collection

Pretrial research of prospective jurors should only be used for proper purpose, namely, to gather information to assist in the exercise of peremptory challenge.

2 Use of information

Information about prospective jurors gathered through pretrial research should be used only in the exercise of a challenge. The use of the information obtained for personal purposes or any other purpose in inappropriate.

3 Collection of information

(1) Research into the personal background of prospective jurors should be passive only. Lawyers may passively survey prospective jurors' social networking sites and the like but should not attempt to make contact with a prospective juror in any way.

(2) The information collected should be limited to information that is publicly available.

(3) Prospective jurors should be notified that, if a lawyer contacts them in breach of the guidelines, they can report the incident to the registrar of the relevant court.

4 Disclosure of information

(1) Information gathered through pretrial research should be kept confidential.

(2) However, the relevant court may require a lawyer to disclose the method used to obtain information on prospective jurors if a prospective juror reports an incident to the registrar of the relevant court under Guideline 3(2). 
Information collected for the purposes of challenge should not be retained after the jury for which

the research was conduct has been secured.

Guidelines 1 and 2 deal with the proper purpose of pretrial research and the proper use of information collected. Information should only be collected with a view to challenge. Any ulterior purpose for collecting information, such as a personal motivation, is outside the scope of the lawyer's duty to the court and client. Likewise, the proper use of information gathered through pretrial research is limited to the exercise of a challenge. Guidelines on the method of collection are equally necessary in ensuring that pretrial research does not interfere with privacy interests of prospective jurors. Setting out appropriate methods for collection of information also protects lawyers from facing allegations of impropriety in conducting pretrial research. Guideline 3(3) operates as both a policing mechanism of lawyers' conduct, and also as a protective mechanism by providing prospective jurors with an avenue of complaint.

Guidelines 4 and 5 address any privacy concerns held by prospective jurors. Some prospective jurors may feel unease at having personal information being stored long after the jury selection process is over or shared with other people. Thus it is suggested that information should not be retained any longer than needed to exercise a challenge. Further, lawyers need not disclose information to persons not acting for the party that they represent. There is a caveat on the guideline for non-disclosure in instances where a prospective juror has reported behaviour of a lawyer in accordance with Guideline 3(3) in order to allow the registrar of the relevant court to investigate such reports.

As acknowledged earlier, the nature of the internet makes effective policing of online research difficult. These guidelines focus on the appropriate way to conduct research on prospective jurors. As such, the guidelines do not provide a fail-safe method of controlling the practice of pretrial research of prospective jurors, but rather they are consistent with the overriding duty of lawyers to the court and their client in order to regulate the practice fairly.

\section{CONCLUDING COMMENTS}

The use of the internet to research prospective jurors with a view to peremptory challenge has received little attention in New Zealand and, as acknowledged earlier, it is unclear just how widespread or common the practice is among New Zealand lawyers. At the heart of the fears surrounding the use of technology by various parties in a trial setting is the concern to protect the fundamental right to a fair trial. It is argued that, rather than aiming to place jurors "on trial", pretrial research of prospective jurors seeks to protect, rather than undermine, the right to a fair trial by giving lawyers a more informed basis on which to exercise peremptory challenge. Pretrial research of prospective jurors allows lawyers to access information, which may show actual or perceived biases, and prevents reliance on inaccurate and discriminatory stereotypes based on jurors' particulars. 
Embracing the internet as a tool to obtain personal information about prospective jurors has the potential to revitalise the exercise of the peremptory challenge by increasing the impartiality of the jury, and the defendant's confidence in the final verdict. It is also suggested that the practice would enable a more zealous representation of clients by lawyers. As discussed, concerns about juror privacy arise more in relation to juror perception rather than in fact, as the information gathered is limited to publicly available information. However, legislative amendment would be needed to protect the safety of jurors in regard to self-represented defendants. Such protection could be achieved by simply extending the provisions in the Juries Act under which a lawyer may be appointed to act for self-represented defendants for the purposes of challenge.

At a more fundamental level, the rapid development of digital technology has left the court system at somewhat of a crossroads. In the context of the peremptory challenge, technological advancement can either be embraced as a tool that serves to enhance and streamline current systems and processes, or it can be resisted, possibly at the expense of growth and development. Rather than resisting the use of the internet to research jurors, courts should endeavour to manage it by issuing guidelines to ensure that all parties to a proceeding receive a fair trial. The guidelines proposed highlight the appropriate method for conducting pretrial research and outline the parameters within which pretrial research is permitted. 